\title{
Effects of Ash Application on Cadmium Concentration in Small Mammals
}

\section{Lodenius, M.}

American Society of Agronomy, Crop Science Society of America, and Soil Science Society of America

2002

Lodenius, M. et al. 2002. Effects of Ash Application on Cadmium Concentration in Small pÿMammals. Journal of Environmental Quality 31:188 192.

http://hdl.handle.net/1975/177

Downloaded from Helda, University of Helsinki institutional repository.

This is an electronic reprint of the original article.

This reprint may differ from the original in pagination and typographic detail.

Please cite the original version. 


\title{
Effects of Ash Application on Cadmium Concentration in Small Mammals
}

\author{
Martin Lodenius, ${ }^{*}$ Ali Soltanpour-Gargari, Esa Tulisalo, and Heikki Henttonen
}

\begin{abstract}
In order to assess the effects of wood ash application to forests on small mammals, we collected bank voles (Clethrionomys glareolus) and common shrews (Sorex araneus) from a forest area in southern Finland. Part of the sample population was from sites that had been treated with ash 1.5 years earlier, part from untreated control sites. The ash increased the soil $\mathrm{pH}$ and gave an average cadmium load in soil of $44 \mathrm{~g} \mathrm{ha}^{-1}$. When comparing treated and control areas, we found slightly but significantly lower Cd concentrations in vole muscle, liver, and kidney from treated plots, whereas the Cd concentrations in shrew tissues were greater in animals from treated plots. In voles we detected an increase in Cd concentrations during the 45-d sampling period in treated and untreated plots. The relative weight of kidneys was greater from the ash-treated areas than untreated areas for both voles and shrews. The difference in $\mathrm{Cd}$ concentrations between the voles and shrews could be explained by the different food habits.
\end{abstract}

$A^{\text {pras }}$ Proximately $100000 \mathrm{Mg}$ of wood ash is generated each year in Finland. This ash could be used as fertilizer in forests, but the high concentration of cadmium calls for restrictions on the amount of ash applied and the frequency with which it is used. Application of ash affects both soil $\mathrm{pH}$ and element concentrations. Areas subjected to ash application should be monitored over extended periods in order to evaluate the potential for harmful effects to the environment.

The purpose of this investigation was to study the effects of ash application on cadmium concentrations in small mammals: herbivorous bank voles and insectivorous common shrews. The bank voles eat leaves and young shoots of dicot forbs and dwarf shrubs, and flowers and berries of bilberry (Vaccinium myrtillus L.). Bank voles also eat mushrooms in late summer and autumn. Their diet may also include some insects (Hansson, 1985). The shrews eat mostly earthworms, insects, and spiders (Pernetta, 1976; Saarikko, 1989).

Small mammals have been used as biological indicators for several reasons: they are rather easy to collect, they move within a limited areas, and it is possible to use both herbivorous and carnivorous species (e.g., Ma et al., 1991; Pankakoski et al., 1994). Environmental pollutants often concentrate in the liver and kidney of mammals, whereas the concentrations in muscle tissue remain near a background concentration. The concentrations of heavy metals and other harmful substances often accumulate with increasing age of the receptors; consequently, it is important to take the age structure of sampled populations into account when considering

Martin Lodenius, Ali Soltanpour-Gargari, and Esa Tulisalo, Dep. of Limnology and Environmental Protection, P.O. Box 62, FIN-00014 Univ. of Helsinki, Finland. Heikki Henttonen, Finnish Forest Research Institute, Vantaa Research Centre, P.O. Box 18, FIN01301 Vantaa, Finland. Received 18 Dec. 2000. *Corresponding author (martin. lodenius@helsinki.fi).

Published in J. Environ. Qual. 31:188-192 (2002). the effects of pollutants, a factor neglected in many investigations.

\section{MATERIALS AND METHODS}

Three study plots treated with ash and two control plots with no ash applied were chosen around two small lakes, Tavilampi and Nimetön, located about $1 \mathrm{~km}$ apart in Evo, southern Finland $\left(61^{\circ} 14^{\prime} \mathrm{N}, 25^{\circ} 12^{\prime} \mathrm{E}\right)$. The area of each plot was approximately two hectares. The soils at these sites were formed on moraine deposits and in peat, and the forests contain stands of Scots pine (Pinus sylvestris L.) and Norway spruce [Picea abies (L.) H. Karst] with some deciduous birch (Betula spp.) and alder (Alnus spp.) trees. Clear-cutting has been carried out on some parts of the study areas but not on the study plots.

Approximately $4.8 \mathrm{Mg} \mathrm{ha}^{-1}$ of wood ash (dry weight) was applied in February 1998. This ash contained $9.2 \mu \mathrm{g} \mathrm{g}^{-1}$ (dry weight) of cadmium that gave an single average load of $44 \mathrm{~g}$ $\mathrm{Cd} \mathrm{ha}{ }^{-1}$. This amount exceeded the $3 \mathrm{~g} \mathrm{Cd} \mathrm{ha}^{-1} \mathrm{yr}^{-1}$ limit permitted for $\mathrm{Cd}$ in sewage sludge application to Finnish farms. The ash was applied manually and resulted in a rather uneven distribution. In summer 1999 the ash application resulted in an increase in surface $(0-7 \mathrm{~cm})$ soil $\mathrm{pH}\left(\mathrm{H}_{2} \mathrm{O}\right)$ from an average of 4.4 to 5.8 in mineral soils and from 4.5 to 6.1 in peat soils (Pihlström et al., 1999).

Small mammals were collected from 27 July 1999 through 9 Dec. 1999 by using 75 to 80 snap traps baited with bread or oat grains. The species studied were bank vole and common shrew, and 106 voles and 80 shrews represented both sexes and different age classes (Table 1). Plot borders were avoided when sampling treated plots in order to minimize the influence from uncontaminated areas. Body weight, body length, sex, age, and maturity were recorded. The numbers of animals trapped were: 3.7 and 3.9 individual voles per 100 trap-nights from treated and untreated areas, respectively, and 5.1 and 6.7 individual shrews per 100 trap-nights from treated and untreated areas, respectively.

The voles were age-classified as juveniles ( $0.5-1$ month in age and not breeding), subadults (23 months, not breeding and with delayed maturation), young adults (34 months and breeding), and overwintered (about 1 year and breeding) (Prévot-Julliard et al., 1999). The shrews were divided into summer born, nonbreeding juveniles, and overwintered adults (Churchfield, 1990). The trapped animals were frozen in toto as soon as possible after collection.

Tissue samples were taken in the laboratory from leg muscle, liver, and kidney, then dried overnight at $110^{\circ} \mathrm{C}$. All samples were analyzed in duplicate for $\mathrm{Cd}$. Weighed samples $(<0.2 \mathrm{~g}$ dry weight $)$ were digested and heated in glass tubes with $2 \mathrm{~mL}$ of $\mathrm{HNO}_{3}$ (Aristar; BDH Laboratory Supplies Ltd., Poole, UK) for $2 \mathrm{~h}$ at $50^{\circ} \mathrm{C}$, then for 16 to $18 \mathrm{~h}$ at $110^{\circ} \mathrm{C}$. A 2-mL aliquot of $\mathrm{H}_{2} \mathrm{O}_{2}$ was added, and the samples were heated for an additional $6 \mathrm{~h}$ at $110^{\circ} \mathrm{C}$. The digested samples were then filtered and diluted with distilled water to $10 \mathrm{~mL}$. Finally, the sample solutions were analyzed for $\mathrm{Cd}$ concentrations using a graphite furnace atomic absorption spectrometer (AAS) (Varian [Palo Alto, CA] SpectrAA 400 equipped with a GTA-96). The accuracy of our method was tested with a standard reference material (Bovine liver; NIST SRM 1577a, with certified $\mathrm{Cd}$ concentration of $0.44 \pm 0.06 \mu \mathrm{g} \mathrm{g}^{-1}$ ) for 
Table 1. Body weight (g, wet weight) and body length $(\mathrm{mm})$ for bank voles and common shrews. The mean dry weights $( \pm$ SD) of organs and the percent of fresh weight for muscle tissue were: (shrew) liver $30 \pm 1.1$; kidney $28 \pm 1.5$; muscle $28 \pm 1.2 \%$; and (vole) liver $27 \pm 1.3$; kidney $26 \pm 2.0$; muscle $25 \pm 1.6 \%$. Values are means \pm standard deviations with ranges in parentheses.

\begin{tabular}{|c|c|c|c|c|c|c|}
\hline \multirow[b]{2}{*}{ Stage } & \multicolumn{3}{|c|}{ Untreated areas } & \multicolumn{3}{|c|}{ Treated areas } \\
\hline & $n$ & Body weight & Body length & $n$ & Body weight & Body length \\
\hline \multirow[b]{2}{*}{ Juvenile } & & \multicolumn{2}{|r|}{ Bank vole } & \multicolumn{2}{|r|}{$\mathbf{g}$} & $\mathbf{m m}$ \\
\hline & 6 & $10 \pm 2.0(8.5-14)$ & $68 \pm \overline{9.8(50-80)}$ & 5 & $10 \pm 1.9(7.7-13)$ & $65 \pm 9.9(52-78)$ \\
\hline Subadult & 26 & $17 \pm 1.2(14-19)$ & $85 \pm 3.0(80-92)$ & 35 & $16 \pm 1.8(13-19)$ & $84 \pm 5.3(72-95)$ \\
\hline Young adult & 13 & $21 \pm 3.2(16-26)$ & $91 \pm 5.7(85-100)$ & 14 & $21 \pm 3.0(17-26)$ & $92 \pm 4.9(85-100)$ \\
\hline Over wintered & 2 & 31,32 & 100,110 & 1 & 22 & 90 \\
\hline \multicolumn{7}{|c|}{ Common shrew } \\
\hline Juvenile & 38 & $6.9 \pm 0.46(5.6-7.9)$ & $61 \pm 2.8(55-67)$ & 38 & $7.3 \pm 0.41(6.0-8.5)$ & $61 \pm 3.8(50-70)$ \\
\hline Adult & - & - & - & 4 & $9.5 \pm 0.64(8.9-10)$ & $68 \pm 2.1(65-70)$ \\
\hline
\end{tabular}

which we obtained an average value of $0.45 \pm 0.01 \mu \mathrm{g} \mathrm{g}^{-1}$. Our detection limit was $0.01 \mu \mathrm{g} \mathrm{g}^{-1}$. Differences between samples from animals trapped in treated or untreated areas were tested by two sample $t$ tests. If the distribution was not normally distributed, the Wilcoxon rank sum test was applied, and Statistix 7.0 software (Analytical Software, 2000) was used for statistical calculations.

\section{RESULTS}

We found no significant differences in cadmium concentrations between sampling plots within treatments, so our samples were pooled into treated (three sampling plots) and untreated (two sampling plots) groups. We detected no significant differences between treated and control areas in the number of trapped animals or in body weight or body length of the animals.

\section{Cadmium Concentration in Voles}

Body size (length and weight) of voles did not vary between treated and untreated areas. This similarity was seen for all age classes except overwintered adults, of which only two individuals were collected from untreated areas and only a single individual from the treated areas (Table 1). No significant differences in $\mathrm{Cd}$ concentrations were observed between male and female individuals in any age class (data not shown). The ratio of liver weight to whole body weight was not statistically significant, but the ratio of kidney weight to body weight was significantly greater for animals from treated areas than from untreated areas (Table 2). Overall, Cd concentrations were greater in tissues from voles trapped from untreated areas than treated areas (Table 3). Muscle, liver, and kidney tissues from animals trapped in the untreated areas were significantly greater in juveniles and subadults, but there was no significant difference in the young adults from treated and untreated areas. Absolute differences in $\mathrm{Cd}$ concentrations were generally on the order of 0.1 to $0.3 \mu \mathrm{g} \mathrm{g}^{-1}$ (Table 3), and there was a general increase in Cd concentrations during the 45-d sampling period in all animals (Fig. 1). The number of overwintered individuals trapped in either untreated or treated areas was too small for statistical comparison.

\section{Cadmium Concentration in Shrews}

The relative liver size was not significantly different between shrews trapped in treated or untreated areas, but the ratio of kidney weight to body weight was significantly higher in treated areas (Table 4). The Cd concentrations in kidney and liver tissues from juvenile shrews trapped in the treated areas were significantly greater than those from juvenile shrews trapped in the untreated areas (Table 5); because no adults were trapped in untreated areas, no comparison could be made with adults from treated areas. In addition, shrews also showed greater $\mathrm{Cd}$ concentrations in all tissues than did voles (Tables 3 and 5).

\section{DISCUSSION}

The application of ash has a limited effect on the uptake of cadmium in voles and shrews within a short period of time, even though more $\mathrm{Cd}$ was measured in shrews from treated areas than untreated areas. However, ash application increases the amount of cadmium present in the ecosystem. The liming effect of ash will last for a few years, hence $\mathrm{Cd}$ concentrations should be monitored for a much longer period of time than the study period. In a forest area treated with sludge of mixed domestic-industrial origin, Nickelson and West (1996) found significantly elevated Cd concentrations in shrews (Sorex spp.) compared with control areas. This difference between forest areas remained similar 2 and 11 years after sludge application.

The mobility of small mammals depends on age, sex, reproductive status (functional group), and population density. The mobility of voles and shrews is at a maximum for adult males when the population density is low and covers an area of approximately 1 to 2 ha. At greater density, home ranges of males shrink to 0.5 ha. Breeding females have territories of about 0.2 to $0.3 \mathrm{ha}$, and the home range of juvenile and subadult voles is approximately 0.1 ha (Bondrup-Nielsen and Karlsson, 1985; Henttonen, 2000). Our samples of shrews and voles mainly consisted of young animals with reduced

Table 2. Relative weights of liver and kidney as percentages of whole-body weights of bank voles (means \pm standard deviations, with ranges in parentheses), over wintered animals excluded. The $p$ value is the probability that the means of the animals from treated and untreated areas are the same ( $t$ test).

\begin{tabular}{lccc}
\hline & Untreated $(n=45)$ & Treated $(n=54)$ & $p$ \\
\hline Liver/body, \% & $1.4 \pm 0.41(0.65-2.5)$ & $1.6 \pm 0.50(0.65-3.5)$ & 0.479 \\
Kidney/body, \% & $\mathbf{0 . 3 3} \pm \mathbf{0 . 0 8}(\mathbf{0 . 2 1 - 0 . 5 9 )}$ & $\mathbf{0 . 3 6} \pm \mathbf{0 . 1 0}(\mathbf{0 . 1 6 - 0 . 6 1 )}$ & $\mathbf{0 . 0 6 3}$
\end{tabular}


Table 3. Cadmium concentrations ( $\mu \mathrm{g} \mathrm{g}^{-1}$ dry weight) in bank vole tissues. Means \pm standard deviations and ranges (in parentheses) are shown, and the number of samples is indicated for the samples from untreated and treated areas. The $p$ value is the probability that the means of animals from treated and untreated areas are the same $(t$ test).

\begin{tabular}{|c|c|c|c|c|c|c|}
\hline \multirow[b]{2}{*}{ Tissue } & \multicolumn{2}{|c|}{ Untreated areas } & & \multicolumn{2}{|c|}{ Treated areas } & \multirow[b]{2}{*}{$p$} \\
\hline & $n$ & Concentration & & $n$ & Concentration & \\
\hline \multirow{2}{*}{\multicolumn{4}{|c|}{$\boldsymbol{\mu g} \mathbf{g}^{-1}$}} & \multirow{2}{*}{\multicolumn{3}{|c|}{$\mu \mathbf{g ~ g}^{-1}$}} \\
\hline & & & Juveniles & & & \\
\hline Muscle & 6 & $0.35 \pm 0.20(0.03-0.66)$ & & 5 & $0.07 \pm 0.06(0.02-0.17)$ & 0.025 \\
\hline Liver & 6 & $1.3 \pm 0.76(0.10-2.3)$ & & 5 & $0.27 \pm 0.22(0.03-0.66)$ & 0.025 \\
\hline Kidney & 6 & $1.0 \pm 0.51(0.17-1.7)$ & & 5 & $0.30 \pm 0.18(0.10-0.54)$ & 0.150 \\
\hline \multicolumn{7}{|c|}{ Subadults } \\
\hline Muscle & 26 & $0.08 \pm 0.06(0.01-0.22)$ & & 35 & $0.04 \pm 0.03(<0.01-0.13)$ & 0.0002 \\
\hline Liver & 26 & $0.37 \pm 0.16(0.12-0.79)$ & & 35 & $0.23 \pm 0.11(0.06-0.56)$ & 0.001 \\
\hline Kidney & 26 & $1.1 \pm 0.50(0.29-2.0)$ & & 35 & $0.72 \pm 0.44(0.08-2.1)$ & 0.019 \\
\hline \multicolumn{7}{|c|}{ Young adults } \\
\hline Muscle & 13 & $0.05 \pm 0.04(0.01-0.16)$ & & 14 & $0.08 \pm 0.14(<0.01-0.53)$ & 0.279 \\
\hline Liver & 13 & $0.38 \pm 0.21(0.13-0.81)$ & & 14 & $0.35 \pm 0.18(0.17-0.68)$ & 0.730 \\
\hline Kidney & 13 & $1.6 \pm 1.1(0.32-3.6)$ & & 14 & $1.6 \pm 0.99(0.64-3.8)$ & 0.908 \\
\hline \multicolumn{7}{|c|}{ Over wintered } \\
\hline Muscle & 2 & $0.05,0.08$ & & $\mathbf{1}$ & 0.03 & - \\
\hline Liver & 2 & $0.39,0.81$ & & 1 & 0.47 & - \\
\hline Kidney & 2 & $3.7,4.9$ & & 1 & 1.7 & - \\
\hline
\end{tabular}

home ranges, and our results appear to reflect the conditions for $\mathrm{Cd}$ at the study plots.

The concentrations of Cd in livers of bank voles from our study area were similar to those recorded near a lead smelter and at a control area in southern Finland. The concentrations in liver and kidney of common shrews from both treated and untreated plots were slightly less than in samples collected around a smelter in Harjavalta, southwestern Finland (Pankakoski et al., 1994). Bergbom (1987; also cited in Nuorteva, 1990) studied $\mathrm{Cd}$ concentrations in Finnish bank voles and common shrews, and found an average concentration of $0.78,0.68$, and $3.2 \mu \mathrm{g} \mathrm{g}^{-1}$ (dry weight) in muscle, liver, and kidney, respectively, in voles, whereas the concentrations were 1.3, 3.3, and $6.9 \mu^{-1} \mathrm{~g}^{-1}$ (dry weight) in shrews. In an area close to Evo, Ukonmaanaho et al. (1998) reported $2.7 \mu \mathrm{g} \mathrm{g}^{-1}$ (dry weight) as a median value for liver of common shrew $(n=40)$. We conclude that results from our study area (both control and treated plots) fall within the range of normal cadmium levels for small mammals in Finland.

Hunter et al. (1989) compared the cadmium concentrations in common shrew from one contaminated and one uncontaminated area. The average muscle concentration from shrews in untreated areas was $1.1 \mu \mathrm{g} \mathrm{g}^{-1}$ (dry weight), the liver concentration $14 \mu \mathrm{g} \mathrm{g}^{-1}$ (dry weight), and the kidney concentration $21 \mu \mathrm{g} \mathrm{g}^{-1}$ (dry weight). In the contaminated area the concentrations were $4.8 \mu \mathrm{g} \mathrm{g}^{-1}$ (dry weight) in muscle, $580 \mu \mathrm{g} \mathrm{g}^{-1}$ (dry weight) in liver, and $250 \mu \mathrm{g} \mathrm{g}^{-1}$ (dry weight) in kidney, and were much greater than our results. Also, Read and Martin (1993) found considerably larger concentrations than reported in our study in common shrew at varying distances from a smelter in southwest England.

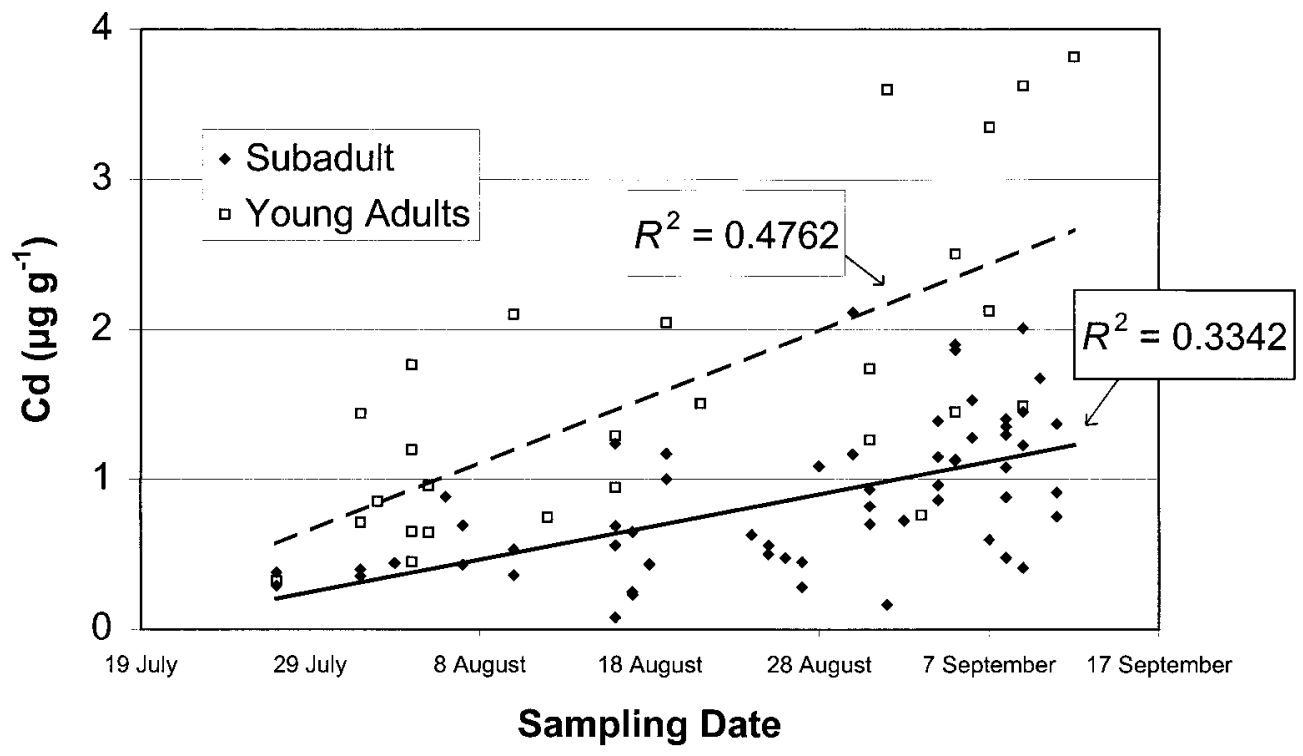

Fig. 1. Kidney Cd concentrations ( $\mu \mathrm{g} \mathrm{g}^{-1}$ ) in subadult (closed symbol, solid line) and young adult (open symbol, dashed line) bank voles in relation to sampling time. 
Table 4. Relative weights of liver and kidney as percentages of whole-body weights of common shrews (means \pm standard deviations with ranges in parentheses), over wintered specimens excluded. The $p$ value is the probability that the means of the animals from treated and untreated areas are the same $(t$ test).

\begin{tabular}{lccc}
\hline & Untreated $(n=38)$ & Treated $(n=38)$ & $p$ \\
\hline Liver/body, \% & $1.7 \pm 0.24(1.1-2.1)$ & $1.8 \pm 0.22(1.2-2.1)$ & 0.311 \\
Kidney/body, \% & $\mathbf{0 . 4 2} \pm \mathbf{0 . 0 5}(\mathbf{0 . 2 9 - 0 . 5 4 )}$ & $\mathbf{0 . 4 3} \pm \mathbf{0 . 0 7}(\mathbf{0 . 2 3 - 0 . 5 5 )}$ & $\mathbf{0 . 0 7 3}$ \\
\hline
\end{tabular}

The effects of liming and the associated increase in $\mathrm{pH}$ on distribution and uptake of cadmium is not clear. Pascoe et al. (1994) found the bioavailability of As, Cd, $\mathrm{Cu}, \mathrm{Pb}$, and $\mathrm{Zn}$ to small mammals to be quite small. Pankakoski et al. (1994) argue that ash application increases the $\mathrm{pH}$ of soil, thereby decreasing the mobility of $\mathrm{Cd}$. Earthworms and/or insects possibly take up Cd from the ash and thereby make it more bioavailable to shrews that consume them than to voles that are herbivores.

In an area heavily polluted by the metal industry (Budel) in the Netherlands, Ma et al. (1991) found Cd concentrations of 0.36 and $2.0 \mu \mathrm{g} \mathrm{g}^{-1}$ (dry weight) in liver and kidney, respectively, from the field vole (Microtus agrestis $)$ and smaller concentrations of $\mathrm{Cd}\left(0.12 \mu \mathrm{g} \mathrm{g}^{-1}\right.$ and $0.20 \mu \mathrm{g} \mathrm{g}^{-1}$ ) in a slightly polluted (Arnhem) area. In common shrews from the same study, the concentrations were 180 and $140 \mu \mathrm{g} \mathrm{g}^{-1}$ in liver and kidney, respectively, in the heavily polluted area and 28 and $32 \mu \mathrm{g} \mathrm{g}^{-1}$, respectively, in the slightly polluted area. The cadmium concentrations in voles from our treated and untreated plots were similar to those reported from the Netherlands, while the concentrations in shrews were much lower than even the less polluted area in the Netherlands. The estimated daily intake of $\mathrm{Cd}$ at Budel and Arnhem for M. agrestis was 0.3 and $0.2 \mu \mathrm{g} \mathrm{g}^{-1} \mathrm{~d}^{-1}$ in the heavily and less-polluted areas, respectively, in the Netherlands; for common shrew the estimated intake was 14 and $5.7 \mu \mathrm{g} \mathrm{g}^{-1} \mathrm{~d}^{-1}$ (Ma et al., 1991). In a laboratory experiment Swiergosz et al. (1998) found that an average intake of $15 \mu \mathrm{g} \mathrm{g}^{-1}$ of food for three months results in a concentration of $15 \mu \mathrm{g} \mathrm{g}^{-1}$ in kidney of bank voles. In our study area the average ingestion of $\mathrm{Cd}$ from bilberry leaves in 1999 was $0.14 \mu \mathrm{g} \mathrm{Cd} \mathrm{g}^{-1}$ from treated plots and $0.07 \mu \mathrm{g} \mathrm{g}^{-1}$ from untreated plots (Pihlström et al., 1999). Insects and earthworms from the treated and untreated areas have not yet been studied.
The difference between Cd concentrations in common shrew from untreated and treated areas was much smaller than in samples of Trowbridge's shrew (Sorex trowbridgii) collected from forest areas treated with sewage sludge, where the renal Cd was 3.6 times greater and the hepatic $\mathrm{Cd} 8.5$ times greater than in samples from control areas (Hegstrom and West, 1989). We found the same tissue distribution of cadmium for all functional groups in both species: kidney $>$ liver $>>$ muscle. Accumulation of $\mathrm{Cd}$ in tissues of common shrew is shown to increase with increasing age (Pankakoski et al., 1994). According to Hunter et al. (1989), more than $90 \%$ of Cd is accumulated in liver, kidney, and pancreas, and less than $10 \%$ in other parts of the body, mainly bones and muscles of common shrew. Hunter et al. (1989) found a significant correlation between total body weight and $\mathrm{Cd}$ in liver and kidney of common shrew that probably reflects the effect of age. The young of the year are several grams lighter than overwintered, older breeding animals. They also suggested the possibility that kidneys became saturated if cadmium exposure is prolonged and that the accumulation continues in the liver. Dodds-Smith et al. (1992b) found that the percentage of cadmium in the liver increases with increasing total body cadmium burden. In a feeding experiment, Dodds-Smith et al. (1992a) found a significant negative effect of the cadmium intake (14-65 mg during 1-12 wk) on the body weight of common shrew.

In a polluted area in northern Sweden, Leffler and Nyholm (1996) estimated that tubular damage in kidneys, indicated by proteinuria and increased urine production, would occur even at concentrations as low as $4 \mu \mathrm{g} \mathrm{g}^{-1}$ (wet weight) in whole kidney of the bank vole. In our study the maximum cadmium concentration in kidney was $4.9 \mu \mathrm{g} \mathrm{g}^{-1}$ (dry weight) corresponding to about $1.2 \mu \mathrm{g} \mathrm{g}^{-1}$ (wet weight). Thus, cadmium-induced toxicological effects seem unlikely in our study area. Our results indicate an increase in the size of kidney and possibly liver of both voles and shrews at higher ash exposure.

Seasonal variations in tissue concentrations of metals have been reported for different organisms. Wlostowski et al. (1996) found that a low ambient temperature $\left(+5^{\circ} \mathrm{C}\right)$ decreases the $\mathrm{Cd}$ accumulation in liver and kidney of bank voles compared with when voles are exposed to $\mathrm{Cd}$ at $20^{\circ} \mathrm{C}$. The low temperature may also

Table 5. Cadmium concentrations $\left(\mu \mathrm{g} \mathrm{g}^{-1}\right)$ in juvenile and adult common shrew tissues. Means \pm standard deviations and ranges (in parentheses) are shown, and the number of samples is indicated for the untreated and treated samples. The $p$ value (Wilcoxon rank sum test) is the probability that the means of the animals from treated and untreated areas are the same.

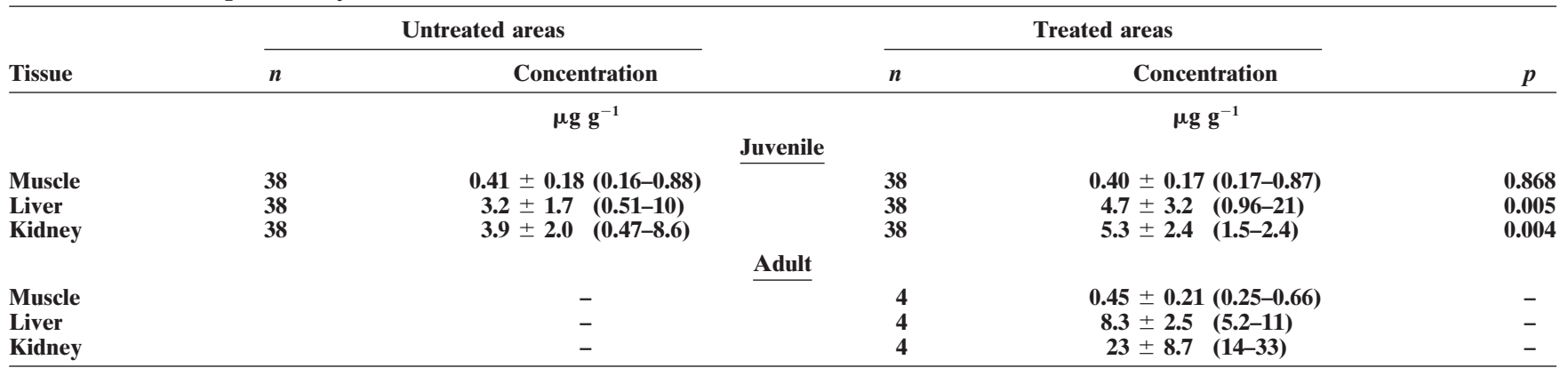


affect the Cd intake through changes in the copper metabolism. Because many species of fungi accumulate considerable amounts of cadmium (e.g., Lodenius et al., 1981), the increasing concentrations toward autumn in bank voles from Evo might be related to the increasing consumption of fungi by voles in the autumn.

The different response of voles and shrews to ash application in different areas is probably related to the different food sources of these herbivorous and insectivorous animals as well as to differences in how the various species respond to contaminants. However, our work shows that further investigations on cadmium accumulation in insects and earthworms are needed to evaluate further the effects of $\mathrm{Cd}$ from ash applications on bank voles and common shrews in Finland.

\section{ACKNOWLEDGMENTS}

We are indebted to Mr. Jussi Vilen for help in collection of samples and Mr. Ahmed Ali Mohamud for help in the analytical work. This study was financed by the Academy of Finland and the Ministry of Environment (Project EEMA).

\section{REFERENCES}

Analytical Software. 2000. Statistix 7.0. Analytical Software, Tallahassee, FL.

Bergbom, K. 1987. Heavy metals in small mammals. (In Swedish.) M.Sc. thesis. Dep. Environ. Conserv., Univ. of Helsinki, Finland.

Bondrup-Nielsen, S., and F. Karlsson. 1985. Movements and spatial patterns of Clethrionomys species: A review. Ann. Zool. Fennici 22:385-392.

Churchfield, S. 1990. The natural history of shrews. Christopher Helm Ltd., London.

Dodds-Smith, M.E., M.S. Johnson, and D.J. Thompson. 1992a. Trace metal accumulation by the shrew Sorex araneus. I. Total body burden, growth, and mortality. Ecotoxicol. Environ. Safety 24:102117.

Dodds-Smith, M.E., M.S. Johnson, and D.J. Thompson. 1992b. Trace metal accumulation by the shrew Sorex araneus. III. Tissue distribution in kidney and liver. Ecotoxicol. Environ. Safety 24:118-130.

Hansson, L. 1985. Clethrionomys food: Generic, specific and regional characteristic. Ann. Zool. Fennici 22:315-318.

Hegstrom, L., and S. West. 1989. Heavy metal accumulation in small mammals following sewage sludge application to forests. J. Environ. Qual. 18:345-349.

Henttonen, H. 2000. Longterm dynamics of the bank vole Clethrionomys glareolus at Pallasjärvi, northern Finnish taiga. Polish J. Ecol. 48(suppl.):87-96.
Hunter, B.A., M.S. Johnson, and D.J. Thompson. 1989. Ecotoxicology of copper and cadmium in a contaminated grassland ecosystem. IV. Tissue distribution and age accumulation in small mammals. J. Appl. Ecol. 26:89-99.

Leffler, P.E., and N.E.I. Nyholm. 1996. Nephrotoxic effects in freeliving bank voles in a heavy metal polluted environment. Ambio 25: $417-420$.

Lodenius, M., T. Kuusi, K. Laaksovirta, H. Liukkonen-Lilja, and S. Piepponen. 1981. Lead, cadmium and mercury content of fungi in Mikkeli, SE Finland. Ann. Bot. Fennici 18:183-186.

Ma, W., W. Denneman, and J. Faber. 1991. Hazardous exposure of ground-living small mammals to cadmium and lead in contaminated terrestrial ecosystems. Arch. Environ. Contam. Toxicol. 20:266270.

Nickelson, S.A., and S.D. West. 1996. Renal cadmium concentrations in mice and shrews collected from forest lands treated with biosolids. J. Environ. Qual. 25:86-91.

Nuorteva, P. 1990. Metal distribution patterns and forest decline seeking Achilles' heels for metals in Finnish forest biocoenoses. Publ. Dep. Environ. Conserv., Univ. of Helsinki, Finland.

Pankakoski, E., I. Koivisto, H. Hyvärinen, and J. Terhivuo. 1994 Shrews as indicators of heavy metal pollution. p. 137-149. In J.F Merritt et al. (ed.) Advances in the biology of shrews. Spec. Publ. 18. Carnegie Museum of Nat. Hist., Pittsburgh, PA.

Pascoe, G.A., R.J. Blanchet, and G. Linder. 1994. Bioavailability of metals and arsenic to small mammals at a mining waste-contaminated wetland. Arch. Environ. Contam. Toxicol. 27:44-50.

Pernetta, J.C. 1976. Diets of shrews Sorex araneus L. and Sorex minutus L. in Wytham grassland. J. Anim. Ecol. 45:899-912.

Pihlström, M., P. Rummukainen, amd A. Mäkinen. 1999. Vegetation and soil research of the ash fertilization project at Evo 1997-1999, final report. (In Finnish.) Metsäteho Ltd., Helsinki, Finland.

Prévot-Julliard, A.C., H. Henttonen, N.G. Yoccoz, and N.C. Stenseth. 1999. Delayed maturation in female bank voles: Optimal decision or social constraint. J. Anim. Ecol. 68:684-697.

Read, H., and M. Martin. 1993. The effect of heavy metals on populations of small mammals from woodlands in Avon (England) with particular emphasis on metal concentrations in Sorex araneus L. and Sorex minutus L. Chemosphere 27:2197-2211.

Saarikko, J. 1989. Foraging behaviour of shrews. Ann. Zool. Fennici 26:411-423.

Swiergosz, R., M. Zakrzewska, K. Sawicka-Kapusta, K. Bacia, and I. Janowska. 1998. Accumulation of cadmium in and its effect on bank vole tissues after chronic exposure. Ecotoxicol. Environ. Safety 41:130-136.

Ukonmaanaho, L., M. Starr, J.-P. Hirvi, A. Kokko, P. Lahermo, J. Mannio, T. Paukola, T. Ruoho-Airola, and H. Tanskanen. 1998. Heavy metal concentrations in various aqueous and biotic media in Finnish Integrated Monitoring catchments. Boreal Environ. Res. 3:235-249.

Wlostowski, T., A. Krasowska, and W. Dworakowski. 1996. Low ambient temperature decreases cadmium accumulation in the liver and kidneys of the bank vole (Clethrionomys glareolus). BioMetals 9: 363-369. 